\title{
MAGNETIC RESONANCE IMAGING OF THE BREAST - WHERE ARE WE IN 2021?
}

\author{
MIRTA ZEKAN VUČETIĆ ${ }^{1}$, SAŠA SCHMIDT ${ }^{1}$, HELGA SERTIĆ MILIĆ ${ }^{1}$, JELENA POPIĆ1, \\ LJUBICA LUETIĆ CAVOR ${ }^{2}$ and BORKI VUČETIĆ ${ }^{3}$
}

\begin{abstract}
${ }^{1}$ Department for Diagnostic and Interventional Radiology, Clinical Hospital Merkur, Zagreb, Croatia; ${ }^{2}$ Clinical Department for Diagnostic and Interventional Radiology, University Hospital for Tumors, Sestre milosrdnice University Hospital Center, Zagreb, Croatia;

${ }^{3}$ Clinical Department for Surgery, Sestre milosrdnice University Hospital Center, Zagreb, Croatia
\end{abstract}

\begin{abstract}
Summary
Magnetic resonance imaging (MRI) is a sensitive and safe radiological method for breast and axillar lymph node imaging. MRI is widely used for diagnostics and follow-up of breast cancer candidates for neoadjuvant chemotherapy. MRI is used to assess tumor response to chemotherapy in these patients and help plan the type of surgical procedure needed after the therapy.

Also, preoperative MRI changes the surgical approach in $11-16 \%$ of the cases and depicts the occult tumor in the contralateral breast in 3-4\% of patients whose primary treatment is surgery.

Several studies in recent years, some on more than a thousand patients, have shown usefulness of breast MRI for planning surgical approaches reducing the number of patients with positive resection margins, thus reducing the number of patients who need reoperation.

In future, we should aim to include MRI of the breast as a diagnostic tool in more, if not all, patients diagnosed with breast cancer.
\end{abstract}

KEYWORDS: breast MRI, neoadjuvant chemotherapy, early breast cancer

\section{INTRODUCTION}

Radiologists introduced breast magnetic resonance imaging (MRI) exams in the early 80s of the twentieth century. The initial results were not encouraging, and these first exams did not prove that MRI was a method superior to conventional mammography (MMG) or ultrasound (US) of the breast. Heywang and al. made a breakthrough in 1986 when they started using an intravenous gadolinium contrast agent for breast MRI(1). Since then, the rapid development of technology and

Corresponding author: Mirta Zekan Vučetić, Department for Diagnostic and Interventional Radiology, Clinical Hospital Merkur, Zajčeva 19, 10000 Zagreb,Croatia.e-mail:mzvucetic@gmail.com software has begun and still lasts until today resulting in improved image acquisition and postprocessing.

Consequently, today we have an excellent method of examination, which is safe and quick, and gradually becomes one of the main tools in diagnosing and follow-up of patients with breast cancer and other breast pathology.

Most Croatian breast cancer centers currently use MRI machines with a magnetic field strenght of 1.5 Tesla (T). Nowadays, more and more radiology departments are acquiring and starting to use 3T MRI machines to improve this examination further. Almost all the patients need to have an intravenous contrast agent administered for this examination. There are a few indications where con- 
trast is not required, mainly when assessing breast implants. Dynamic post contrast sequences and software reconstructed subtraction sequences, MRI provides the detailed imaging of breast and axillar morphology and depicts pectoral muscles and lymph path along mammary blood vessels.

During the examination, the patient lies in the prone position, which, in our experience, makes it somewhat easier to tolerate the examination even in some severely claustrophobic patients. The examination is relatively short, lasts up to 25 minutes (depending on the center and acquisition protocol used), which is also essential for compliance.

Contraindications for this examination are the general contraindications for MRI examinations. Absolute contraindications: cardiac implantable electronic devices, metallic foreign bodies, implantable neurostimulation systems, cochlear implants, drug infusion pumps, cerebral artery aneurysm clips, tissues expanders, hearing aid, and piercing(2). Some of these devices and objects can be easily removed before the examination, and MRI can still be performed.

Regarding the contrast agent, gadoliniumbased contrast agents are considered relatively safe. However, caution is required with patients on dialysis, patients with impaired renal function, patients who have had another intravenous contrast agent administered less than 24 hours ago, and patients who may have had a previous allergic reaction to gadolinium(2).

There is another special consideration regarding MRI of the breast in women of generative age. It is recommended for MRI exam to be performed between the 5th and 12th day of the menstrual cycle, and never later than the 15th day, to avoid false-positive results due to increased background parenchymal enhancement (BPE)(3). In the second part of the cycle, breast parenchyma shows increased contrast agent uptake, thus making it almost impossible for a radiologist to get accurate readings in some patients. The same goes for examination during pregnancy and breastfeeding.

\section{INDICATIONS}

MRI of the breast is not always readily available, and it is an expensive examination during which the intravenous contrast agent is administered. It is crucial to have clear indications. On the other hand, it is also important to make it available for all the patients that can benefit from it.

According to the recent literature, there is a list of indications that is mostly in concordance with National Comprehensive Cancer Network (NCCN) guidelines $(4,5,6)$ :

1) before and after neoadjuvant chemotherapy

2) preoperative evaluation for patients who are candidates for surgery as a primary treatment

3) patients with prevalent glandular parenchy$\mathrm{ma} / \mathrm{suspicion}$ of ductal carcinoma in situ (DCIS)

4) patients with invasive lobular carcinoma

5) patients with breast discharge and/or changes of areolar skin in Paget's disease

6) patients with malignant axillar lymph nodes without a primary tumor of the breast visible with MMG and/or US

7) annual screening in high-risk patients

ESMO Clinical Practice Guidelines from March 2020 are also in concordance with these indications(7).

\section{NEOADJUVANT CHEMOTHERAPY}

Breast MRI in patients that are candidates for neoadjuvant chemotherapy as the primary line of treatment for breast cancer is the most accepted indication for this examination. MRI is used to assess tumor response to treatment and plan the subsequent surgical approach(8).

Breast MRI needs to be performed at least twice in these patients - before the commencement of chemotherapy and upon completion. A number of these patients have already had a core biopsy. In our experience, it has proven useful to wait at least 7-10 days after the biopsy to prevent false-positive results because of the tissue damage from the biopsy.

American College of Radiology Imaging Network (ACRIN) study - ACRIN 6657 form 2018 studied the accuracy of residual tumor measurements using different imaging methods. It concluded that measuring residual tumors with MRI gave more accurate results than with MMG and US(9).

According to Kim et al.(10) there are six types of tumor response to chemotherapy. 

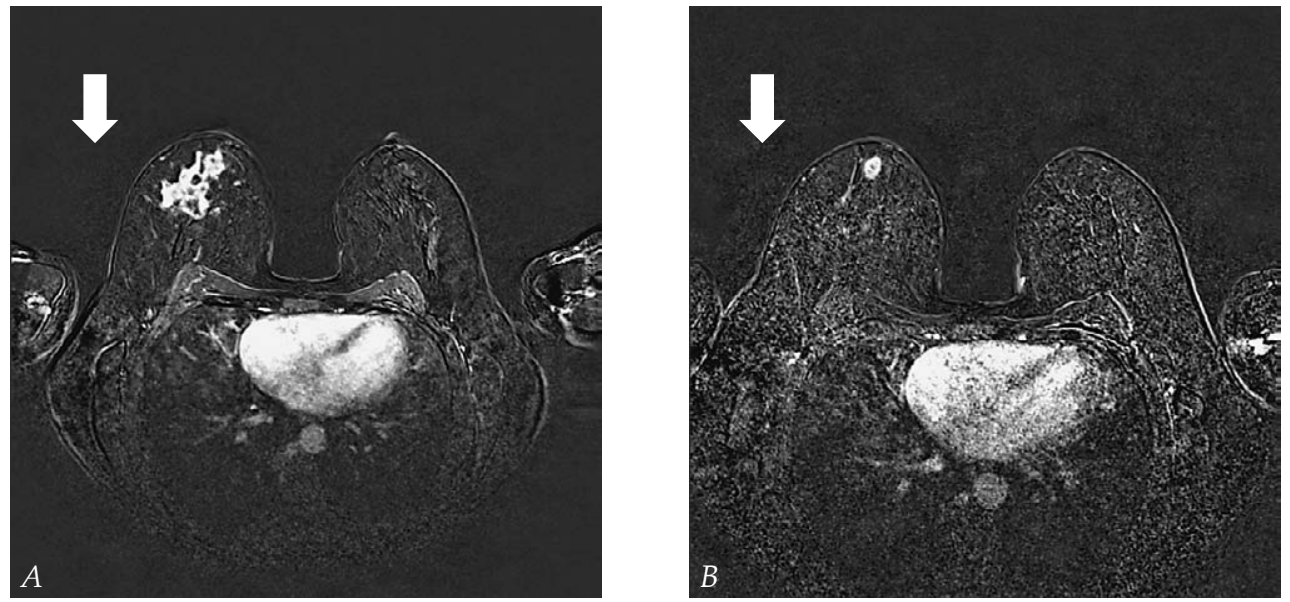

Figure $1 A$ and B: Subtraction sequence. Image before $(A)$ and after $(B)$ neoadjuvant chemotherapy in a patient with triple negative tumor showing concentric shrinking of the tumor (block arrows) after the treatment.

- Type 0 - complete morphological response

- Type 1 - concentric shrinking of the tumor

- Type 2 - fragmenting/crumbling of the tumor

- Type 3 - residual diffuse non-mass contrast enhancement

- Type 4 - stable disease

- Type 5 - progression

It is important to be aware of these different types of tumor responses to chemotherapy to produce the most accurate image analysis since MRI results can impact the planning of the operation.

Overall tumor response and the specific type of tumor response to therapy also depend on the histological type of tumor. Generally, biologically more aggressive tumors - triple negative, HER2 positive, and tumors with high $\mathrm{Ki} 67$ values are more likely to respond better to treatment and respond with concentric tumor-shrinking (Fig 1). Therefore, a radiologist must have this information ready before compiling the final report.

It has been shown that when there is a complete morphological regression on post-chemotherapy breast MRI, there is still a microscopic residual disease in up to $33 \%$ of patients found on the final pathological examination after the surgery. Nevertheless, this kind of tumor response on breast MRI has proven to be a good prognostic factor for predicting overall and recurrence-free 3-year survival(11).

An especially careful evaluation is needed in types 2 and 3 responses because it is not always possible to correctly identify if there is still a residual disease, or if the changes seen of the images represent DCIS, or even in some cases, the response of the surrounding tissue to chemotherapy.

Apart from assessing the tumor, breast MRI also depicts axillar lymph nodes. The radiologist can also describe the response to therapy in previously enlarged and pathologically changed lymph nodes. However, to date, the morphological assessment of lymph nodes after chemotherapy alone has not proven accurate enough for the patients to be referred to a less invasive surgery (sentinel lymph node biopsy). In most cases, in patients with more than one changed lymph node before the chemotherapy, axillar dissection remains the surgery of choice after the completion of treatment(8).

\section{PREOPERATIVE EVALUATION}

The studies have shown that when performed preoperatively in patients having surgery as the first line of treatment, breast MRI changes surgical approach (Fig 2) in $11-16 \%$ of cases. Previously occult tumor of the contralateral breast (Fig 3) is found in 3-4\% of cases. Also, in about $5.5 \%$ of cases, false-positive findings result in a more extensive surgical procedure than neces$\operatorname{sary}(12,13)$.

Concentrating these examinations in specialized centers dealing with breast pathology, where 


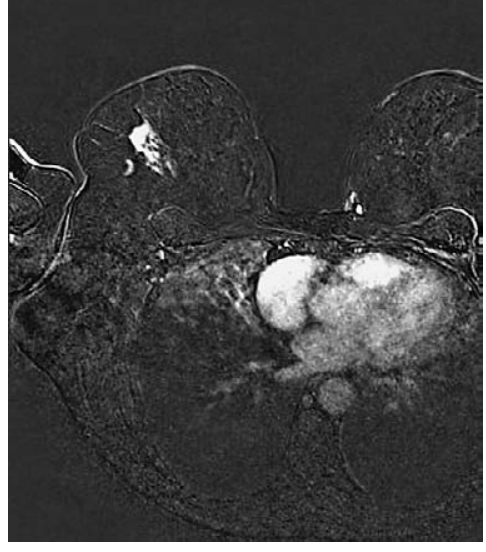

Figure 2. Subtraction sequence. Preoperative MRI. Block arrow points to the portion of tumor seen on the breast US. Small arrows point to the surrounding area of DICS.

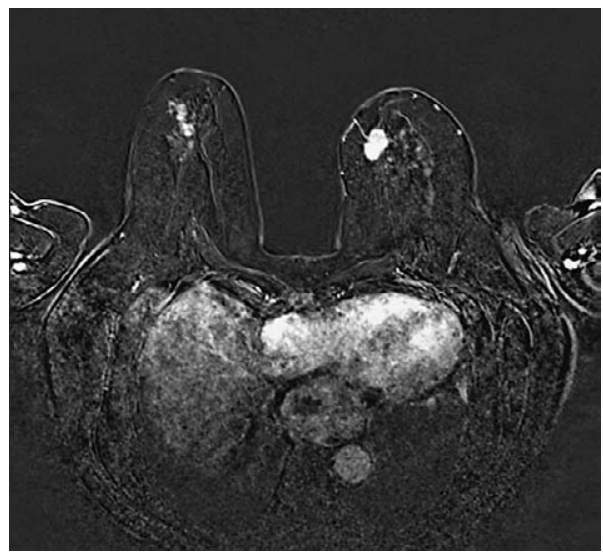

Figure 3. Subtraction sequence. Preoperative breast MR depicts accidental finding in the contralateral (right) breast, which was biopsied and diagnosed as cancer. The patient underwent a bilateral mastectomy and is disease-free four years later.

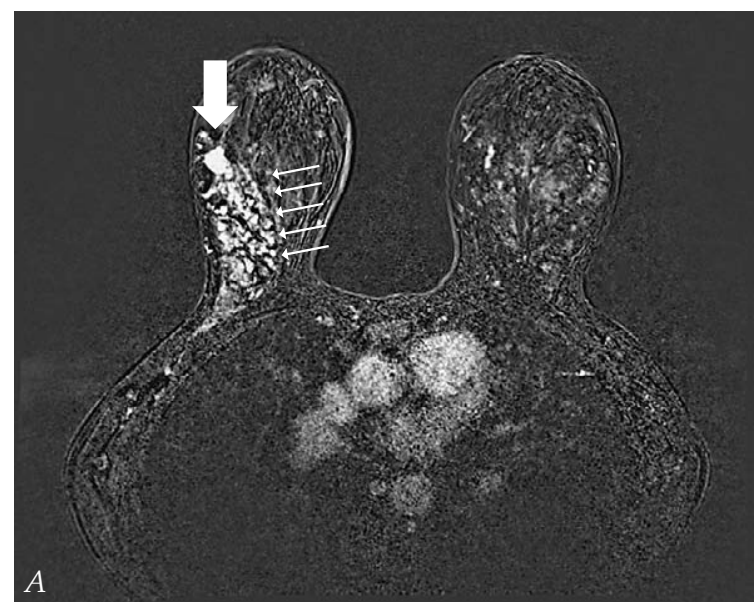

experienced radiologists assess the images, could minimize the false positive findings.

In Croatia, there were 2894 newly diagnosed breast cancers in 2020(14). Divided, it comes to 55 new cases weekly. If further divided between the centers dealing with breast pathology through the country, we reach the number of additional easily covered examinations.

Based on current evidence, there is a clear benefit of routine preoperative breast $\operatorname{MRI}(15,16)$, resulting in fewer tumors with positive resection margins and decreased number of reoperations. Commonly stated downsides of this approach are: examination cost, need for intravenous contrast administration, and prolonged median of waiting for surgery somewhere from 22-39 days, which has a negative psychological effect on the patient. However, in the case of early breast cancer, this psychological effect of waiting time for surgery will not affect overall survival. It can be diminished by accurately explaining the benefits of the preoperative breast MRI to the patient.

\section{DCIS}

MRI has historically been considered not valuable for detecting DCIS of any grade. However, in recent years, with the advancement of MR machines and software, MRI has proven to be highly beneficial in depicting DCIS of all grades

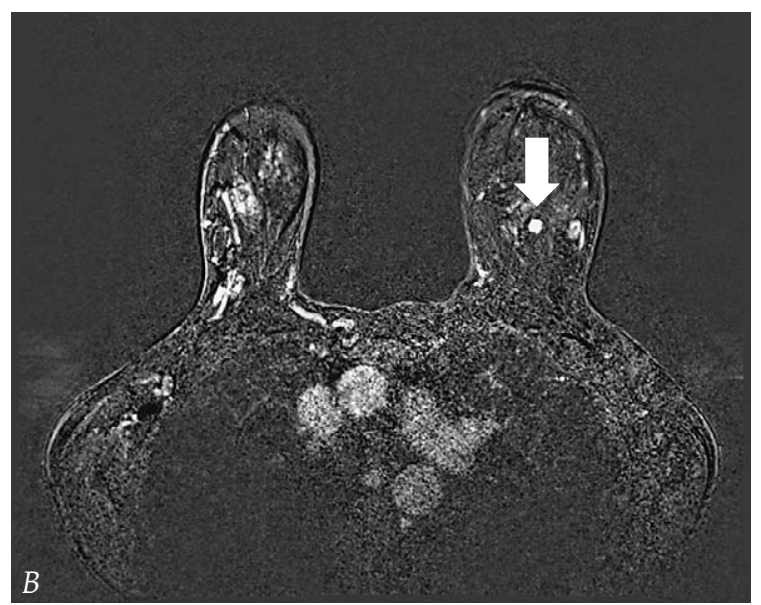

Figure $4 A$ and B. 4 A Block arrow points to the portion of the tumor seen on US. Small arrows point to the large area of lobular carcinoma in situ (LCIS). $4 B$ Block arrow points to a tumor focus in the contralateral breast proven on the postoperative pathology report (it did not show on US or MMG). The patient underwent a bilateral mastectomy and is disease-free 2 years after the surgery. 
and assessing its size, making it an unavoidable tool in preoperative planning(17).

\section{INVASIVE LOBULAR CARCINOMA}

This type of breast cancer is infamous with radiologists for its propensity not to show itself well on MMG and US examinations. There are often subtle changes in many patients with this type of tumor on MMG and US. In case the diagnosis of invasive lobular carcinoma is confirmed, breast MRI is highly useful in uncovering the true extent of the affected tissue (Fig 4, especially in patients with dense parenchymal tissue) and, in some cases, occult, tumor areas in contralateral breast $(18,19)$.

\section{BREAST DISCHARGE/NIPPLE PATHOLOGY - PAGET DISEASE}

Patients with breast discharge that shows atypical cellular changes on cytological examination of the fluid can have normal MMG/US findings. Changes within the excretory ducts can be too subtle for US or MMG to depict. Breast MRI is an excellent examination for identifying and assessing these subtle changes within ducts that can otherwise stay hidden from conventional imaging methods(20).

Patients with Paget's disease of the nipple should also have breast MRI performed. It has been shown that the affected nipple shows postcontrast enhancement on MR scans, showing the extent of the disease more accurately. The same goes for underlying DCIS, which can be seen within the breast in patients with Paget disease of the nipple. These changes are in most cases not seen on MMG/US examinations, thus making breast MRI crucial in uncovering the true extent of the disease $(21,22)$.

\section{THE FUTURE}

As stated above, breast MRI has become an excellent and, in some cases, the most important method for diagnosing and evaluating the local extent of various types of breast cancer and other breast disorders.

However, the development continues.

In recent years, several ongoing studies have used breast MRI during chemotherapy for the ear- ly assessment of tumor response. Goods et al. found that the complete morphological response of the tumor mid-therapy predicts complete pathological response in $83 \%$ of the patients after the surgery(23). The benefit of performing the examination earlier during the treatment has not yet been fully established, and further studies are needed. However, performing this breast MRI mid-therapy could help detect poorly responding patients to chemotherapy earlier, so the oncologist could modify their treatment earlier.

At the moment, several ongoing studies are trying to identify patients with complete responses who might not need the surgery after the completion of chemotherapy. Two of those studies include breast MRI - The Netherlands Cancer Institute MICRA trial(24) and the NRG Oncology Group multicenter trial in the United States(25). These studies combine various imaging techniques with tumor bed biopsy, trying to identify patients with a complete pathological and morphological response before the surgery.

Due to the rapid advancement of technology, new techniques, new sequences, and new models of image acquisition are currently developing. Novel MRI techniques aim to combine functional features of the tumor, such as vascularity, diffusion, metabolism, and hypoxia, to improve MRI image quality.

Furthermore, new developments in radiomics and machine learning models are also being studied and improved for further implementation in clinical settings.

\section{REFERENCES}

1. Heywang S, Fenzl G, Hah D, Krischke I, Edmaier M, Eiermann W, Bassermann R. MR imaging of the breast: comparison with mammography and ultrasound. J Comput Assist Tomogr. 1986;10:615.620.

2. Ghadimi M, Sapra A. Magnetic Resonance Imaging Contraindications. [Updated 2021 May 9]. In: StatPearls [Internet]. Treasure Island (FL): StatPearls Publishing; 2021 Jan.

3. Kajihara M, Goto M, Hirayama Y, Okunishi S, Kaoku S, Konishi E, Shinkura N. Effect of the menstrual cycle on background parenchymal enhancement in breast MR imaging. Magn Reson Med Sci. 2013 Mar 25;12 (1):39-45.

4. NCCN Guidelines for Breast Cancer Version 8.2021

5. Walters MC, Nadalo L. MRI Breast Clinical Indications: A Comprehensive Review. J Am Osteopath Coll Radiol. 2013;2(1):2-17. 
6. Argus A, Mahoney MC. Clinical indications for breast MRI. Appl Radiol. 2010;Oct

7. Cardoso F, Kyriakides S, Ohno S, et al. on behlaf of the ESMO Giudelines Committee. Early Breast Cancer: ESMO Clinical Practice Guidelines for diagnosis, treatment and follow-up. Ann Oncol. 2019;30(8):1194-1220.

8. Reig B, Heacock L, Lewin A, Cho N, Moy L. Role of MRI to assess response to neoadjuvant therapy for breast cancer. J Magn Reson Imaging. 2020 Dec;52(6).

9. Scheel JR, Kim E, Partridge SC, Lehman CD, Rosen MA, Bernreuter WK, et al., ACRIN 6657 Trial Team and I-SPY Investigators Network. MRI, clinical examination, and mammography for preoperative assessment of residual disease and pathologic complete response after neoadjuvant chemotherapy for breast cancer: ACRIN 6657 Trial. AJR Am J Roentgenol. 2018 Jun;210(6):1376-1385.

10. Kim TH, Kang DK, Yim H, Jung YS, Kim KS, Kang SY. Magnetic resonance imaging patterns of tumor regression after neoadjuvant chemotherapy in breast cancer patients: correlation with pathological response grading system based on tumor cellularity. J Comput Assist Tomogr. 2012 Mar-Apr;36(2):200-6.

11. Gampenrieder SP, Peer A, Weismann C, Meissnitzer M, Rinnerthaler G, Webhofer J, et al. Radiologic complete response (rCR) in contrast-enhanced magnetic resonance imaging (CE-MRI) after neoadjuvant chemotherapy for early breast cancer predicts recurrencefree survival but not pathologic complete response (pCR). Breast Cancer Res. 2019 Jan 31;21(1):19.

12. Thompson JL, Wright GP. The role of breast MRI in newly diagnosed breast cancer: An evidence-based review. Am J Surg. 2021 Mar;221(3):525-528.

13. Houssami N, Hayes DF. Review of preoperative magnetic resonance imaging (MRI) in breast cancer: should MRI be performed on all women with newly diagnosed, early stage breast cancer? CA Cancer J Clin. 2009 Sep-Oct;59(5):290-302.

14. Incidencija i mortalitet od raka u EU-27 zemljama za 2020. godinu. Hrvatski zavod za javno zdravstvo. 2020. https://www.hzjz.hr/sluzba-epidemiologija-prevencija-nezaraznih-bolesti/incidencija-i-mortalitet-odraka-u-eu-27-zemljama-za-2020-godinu/ accessed 10/01/2021.

15. Gommers JJJ, Duijm LEM, Bult P, Strobbe LJA, Kuipers TP, Hooijen MJH, Mann RM, Voogd AC. The impact of preoperative breast MRI on surgical margin status in breast cancer patients recalled at biennial screening mammography: An observational cohort study. Ann Surg Oncol. 2021;28(11):5929-5938. doi: 10.1245/s10434-021-09868-1.

16. Rizzo V, Moffa G, Kripa E, Caramanico C, Pediconi F, Galati F. Preoperative Staging in Breast Cancer: Intra- individual Comparison of Unenhanced MRI Combined With Digital Breast Tomosynthesis and Dynamic Contrast Enhanced-MRI. Front Oncol. 2021 May 4;11:661945.

17. Greenwood HI, Wilmes LJ, Kelil T, Joe BN. Role of Breast MRI in the Evaluation and Detection of DCIS: Opportunities and Challenges. J Magn Reson Imaging. 2020 Sep;52(3):697-709.

18. Wong SM, Prakash I, Trabulsi N, Parsyan A, Moldoveanu D, Zhang D, et al. Evaluating the Impact of Breast Density on Preoperative MRI in Invasive Lobular Carcinoma. J Am Coll Surg. 2018 May;226(5):925-932.

19. Parvaiz MA, Yang P, Razia E, Mascarenhas M, Deacon $\mathrm{C}$, Matey $\mathrm{P}$, et al. Breast MRI in invasive lobular carcinoma: a useful investigation in surgical planning? Breast J. 2016 Mar-Apr;22(2):143-50.

20. Cohen E, Leung JWT. Problem-solving MR imaging for equivocal imaging findings and indeterminate clinical symptoms of the breast. Magn Reson Imaging Clin N Am. 2018 May;26(2):221-233.

21. Amano G, Yajima M, Moroboshi Y, Kuriya Y, Ohuchi N. MRI accurately depicts underlying DCIS in a patient with Paget's disease of the breast without palpable mass and mammography findings. Jpn J Clin Oncol. 2005 Mar;35(3):149-53.

22. Kim HS, Seok JH, Cha ES, Kang BJ, Kim HH, Seo YJ. Significance of nipple enhancement of Paget's disease in contrast enhanced breast MRI. Arch Gynecol Obstet. 2010 Aug;282(2):157-62.

23. Goorts B, Dreuning KMA, Houwers JB, Kooreman LFS, Boerma EG, Mann RM, Lobbes MBI, Smidt ML. MRI-based response patterns during neoadjuvant chemotherapy can predict pathological (complete) response in patients with breast cancer. Breast Cancer Res. 2018 Apr 18;20(1):34.

24. van Loevezijn AA, van der Noordaa MEM, van Werkhoven ED, Loo CE, Winter-Warnars GAO, Wiersma T, et al. Minimally invasive complete response assessment of the breast after neoadjuvant systemic therapy for early breast cancer (MICRA trial): interim analysis of a multicenter observational cohort study. Ann Surg Oncol. 2021 Jun;28(6):3243-3253.

25. Basik M, Cecchini R, De Los Santos J, Umphrey H, Julian T, Mamounas E, et al. Primary analysis of NRGBR005, a phase II trial assessing accuracy of tumor bed biopsies in predicting pathologic complete response in patients with clinical/radiological complete response after neoadjuvant chemotherapy to explore the feasibility of breast-conserving treatment without surgery. Conference: 2019 San Antonio Breast Cancer Symposium; December 10-14, 2019; San Antonio, Texas. Abstract GS5-05. 


\section{Sažetak \\ MAGNETNA REZONANCA DOJKI - GDJE SMO 2021? \\ M. Zekan Vučetić, S. Schmidt, H. Sertić Milić, J. Popić, Lj. Luetić Cavor, B. Vučetić}

Magnetna rezonanca (MR) dojki je dobra i sigurna radiološka metoda oslikavanja dojki i aksila. Opće je prihvaćen u dijagnostici i praćenju pacijentica koje su kandidati za neodjuvantnu kemoterapiju raka dojke. MR se kod ovih pacijentica koristi za procjenu odgovora tumora na liječenje, te za planiranje opsega kirurškog zahvata nakon provedenog neoadjuvantnog liječenja.

MR dojki kod pacijentica koje su kandidatkinje za primarno kirurško liječenje mijenja kirurški pristup u oko 11 do 16 \% slučajeva, dok u oko 3-4 \% slučajeva otkriva i dotad nedijagnosticirani proces kontralateralne dojke. Recentnija istraživanja proteklih nekoliko godina, od kojih neka i na više tisuća pacijentica ipak pokazuju značajnu korisnost MR-e dojki u planiranju opsega operativnog zahvata i kod svih pacijentica s ranim rakom dojke koje su kandidatkinje za kirurško liječenje, sa smanjenjem stope pozitivnih resekcijskih rubova na operaciji, te smanjenjem broja potrebnih reoperacija.

U budućnosti bi bilo korisno uvesti pregled MR-om za veći broj, ako ne i za sve pacijentice s dijagnosticiranim rakom dojke prije početka liječenja.

KLJUČNE RIJEČI: MR dojki, neodajuvantna kemoterapija, rani rak dojke 